ISSN 0103-5150

Fisioter. Mov., Curitiba, v. 29, n. 1, p. 23-36, Jan./Mar. 2016

Licenciado sob uma Licença Creative Commons

DOI: http://dx.doi.org.10.1590/0103-5150.029.001.A002

\title{
Relationship among stress, depression, cardiovascular and metabolic changes and physical exercise
}

\author{
Relação entre estresse, depressão, alterações \\ cardiometabólicas e exercício físico
}

\author{
Andrea Sanches ${ }^{[a]}$, Rafaela Costa ${ }^{[a, b]}$, Fernanda Klein Marcondes ${ }^{[a]}$, Tatiana Sousa Cunha ${ }^{[c]}$ \\ [a] Universidade Estadual de Campinas, (FOP/UNICAMP), Piracicaba, SP, Brazil \\ [b] Universidade Estadual de Campinas, (UNICAMP), Campinas, SP, Brazil \\ [c] Universidade Federal de São Paulo, (UNIFESP), São José dos Campos, SP, Brazil
}

\section{Abstract}

Introduction: Stress is considered one of the most significant health problems in modern society. It can be characterized as any changes in the homeostasis of an individual that require an adaptive response. An imbalance in the secretion of the primary stress mediators may be responsible for the onset and development of several diseases. Thus, chronic stress has been recognized as a risk factor for depression as well as cardiovascular and metabolic diseases. Given the pathophysiological mechanisms associated with chronic stress and related cardiovascular and metabolic changes, it is necessary to implement measures to prevent, control and/or avoid their development. Physical exercise is a non-pharmacological resource that is widely used for this purpose. Its beneficial effects include the improvement of the emotional state as well as lipid

* AS: PhD student, e-mail: andreasanches57@gmail.com

RC: PhD, e-mail: rafaela-costa@ig.com.br

FKM: PhD, e-mail: ferklein@unicamp.br

TSC: PhD, e-mail: ts.cunha@unifesp.br 
and glycemic control. Objective: The aim of this review is to discuss the relationship between stress, depression, cardiovascular and metabolic changes, and highlight the importance of physical exercise in the prevention and treatment of resulting disorders. Materials and Methods: We searched MEDLINE and SCIELO from 2000 through 2012, using the terms chronic stress, mood disorders, depression, cardiovascular and metabolic changes, and exercise. Results: Most of the studies found in our literature search have shown that exercise can attenuate and/or reverse the deleterious effects of chronic stress. Conclusion: Regular physical exercise is useful for maintaining health, especially with respect to improving mood and mental stress.

Keywords: Physiological stress. Exercise cardiovascular system. Metabolic diseases.

\section{Resumo}

Introdução: $O$ estresse é um dos mais significativos problemas de saúde na sociedade moderna, podendo ser caracterizado como qualquer mudança na homeostase do indivíduo que requer uma resposta adaptativa. $O$ desequilíbrio na produção dos mediadores primários do estresse pode ser responsável pelo surgimento e desenvolvimento de várias doenças. Dessa forma, o estresse crônico tem sido reconhecido como fator de risco para a depressão e doenças cardiometabólicas. Frente aos mecanismos fisiopatológicos associados ao estresse crônico e às alterações cardiometabólicas correlatas, torna-se necessário encontrar medidas adequadas para preveni-las, controlá-las e/ou evitá-las. Sabe-se que o exercício físico é um recurso não-farmacológico amplamente utilizado para essa finalidade e os efeitos benéficos desencadeados incluem melhora do estado emocional e controle lipídico e glicêmico. Objetivo: 0 objetivo desta revisão foi discutir a relação entre os mecanismos fisiopatológicos do estresse, depressão, alterações cardiometabólicas e a importância da utilização do exercício físico na prevenção e tratamento destas disfunções desencadeadas. Materiais e Métodos: Para esta revisão foram consultadas as bases de dados MEDLINE e SCIELO e inclusos no campo de pesquisa os termos estresse crônico, alterações de humor, depressão, alterações cardíacas e metabólicas e o exercício físico. Como limite de busca, foi definida a pesquisa de artigos publicados entre os anos de 2000 e 2012. Resultados: A maior parte dos estudos mostrou que o exercício é capaz de atenuar e/ou reverter os efeitos deletérios do estresse crônico. Conclusão: A prática regular do exercício físico tem grande utilidade para a manutenção da saúde, sobretudo com relação à melhora do humor e do estresse mental.

Palavras-chave: Estresse fisiológico. Exercício. Sistema cardiovascular. Doenças metabólicas.

\section{Introduction}

Stress is a major cause of cardiovascular and metabolic changes and diseases in developed and developing countries. The absence of adaptive mechanisms essential for restoring homeostatic balance in response to stressful stimuli contributes to the development of dyslipidemias, diabetes, hypertension, and other cardiovascular risk factors $(1,2,3,4)$.

These diseases have a great impact on modern society. Healthcare and work loss costs of persons with chronic diseases such as hypertension, heart disease, diabetes and mood-related disorders have been rising for nearly two decades and might triple by 2030 (5).

Although alarming, such occurrences may be minimized and/or controlled by means of curative or prophylactic measures (either pharmacological or not) (6). Physical exercise has a prominent position in this context, being recognized as a non-pharmacological therapy to avoid and/or mitigate these problems $(7,8,9)$. Although many benefits of exercise are well established from previous research, there is still no consensus about its effects on chronic stress, because exercise can also be recognized as a stress paradigm depending on the way it is used (1). Thus, considering the beneficial effects of physical exercise, the deleterious effects of chronic stress, and the social impact of cardiovascular and metabolic diseases, the aim of this review was to discuss the relationship between stress, depression, cardiovascular and metabolic changes, and highlight the importance of physical exercise in the prevention and treatment of resulting disorders. 


\section{Methods}

We searched MEDLINE and SCIELO for articles on chronic stress, cardiac and metabolic changes, and exercise published between 2000 and 2012. We also included articles published before 2000 in which the concept of stress was defined. In the search, we used the following terms: "physiological stress", "exercise", "cardiovascular system", and "metabolic diseases".

Inclusion criteria were: observational, experimental or review studies conducted to investigate the cardiac and metabolic effects of chronic psychological stress alone or in association with physical activity and exercise, mood disorders and/or depression. Studies investigating the effect of exercise on functions that did not include cardiac and metabolic changes were excluded, as well as studies that did not examine stress-related mood disorders. Articles on other types of stress (other than mental/psychological stress) were also excluded.

\section{Literature Review}

\section{Stress}

Mental stress is considered one of the most significant health problems in modern society. It can be defined as a subjective experience triggered by any aversive stimulus that results in both generalized and nonspecific systemic changes. The term stress was originally employed in physics to describe the degree of deformity sustained by a material when subjected to stress or tension (1). However, it is known that the definition of the word "stress" is based on ancient conceptions dating back to before Christ. These conceptions recognized health as a state of harmony, and disease as a state of disharmony (2).

It was based on these important principles that great physiologists such as Claude Bernard, Cannon and Selye started to correlate the loss of homeostasis with the emergence of diseases. Selye (10) is considered the first to use and popularize the term stress in a physiological sense. This author noted that a series of similar responses were triggered after injection of a particular drug or saline in rats (10). Analyzing the responses obtained, Selye attributed the stimulus caused by the injections (and which seemed to trigger adaptive responses in the body of those animals) to an attempt to maintain homeostasis and face a situation perceived as threatening to the life and internal equilibrium of the animal (10).

Because these stimuli caused generalized and nonspecific hormonal responses - evidenced by the presence of peptic ulcers, atrophy of the immune system and increased adrenal glands - Selye called the phenomenon "general adaptation syndrome". According to the author, it consisted of three phases, namely: alarm or excitement, resistance and exhaustion (11). In the first phase, there is activation of the sympathetic nervous system and adrenal system, with release of catecholamines (by the adrenal medulla) and glucocorticoids (by the adrenal cortex), in order to maintain or restore homeostasis. This restoration leads to the second phase, i.e., resistance. In this phase, the reaction capacity decreases and the body develops adaptive mechanisms to cope with the stressor stimulus. If the stimulus remains, the adaptive response ceases, and the third phase, i.e., exhaustion, begins. This phase is responsible for the deleterious effects triggered by stress, such as cardiovascular disease, metabolic, kidney and immunological disorders, and even death $(10,11,12)$.

Although different organisms respond similarly to the same stressor stimulus, it is known that each organism is not exactly constant and tends to respond differently at times, due to its physiological variations. Thus, the classic definition of stress has been reinterpreted in recent years in the light of this concept and enabled us to see that the mediators of the reaction may have both protective and harmfull effects to the body, depending on the time and intensity of exposure. A new terminology has been used ever since to describe a biological response to an aversive stimulus: allostasis and allostatic load (12) (Figure 1).

According McEwen (12), these two terms allow a more precise and restricted definition of the word "stress". Allostasis may be used to refer to adaptive processes used to maintain the stability of an organism. The main mediators of allostasis are the hormones of the hypothalamus-pituitary-adrenal axis (HPA), catecholamines and cytokines. When these responses vary beyond the limits of homeostatic mechanisms - which exert significant influence over vital functions such as breathing, cardiovascular tone and intermediary metabolism (13) - they are called allostatic load $(1,12)$. Thus, allostatic load causes an imbalance of primary mediators and leads to the overproduction of some of them and the inadequate production of others. This disarray is responsible for the onset and development of various diseases related to stress (12). 


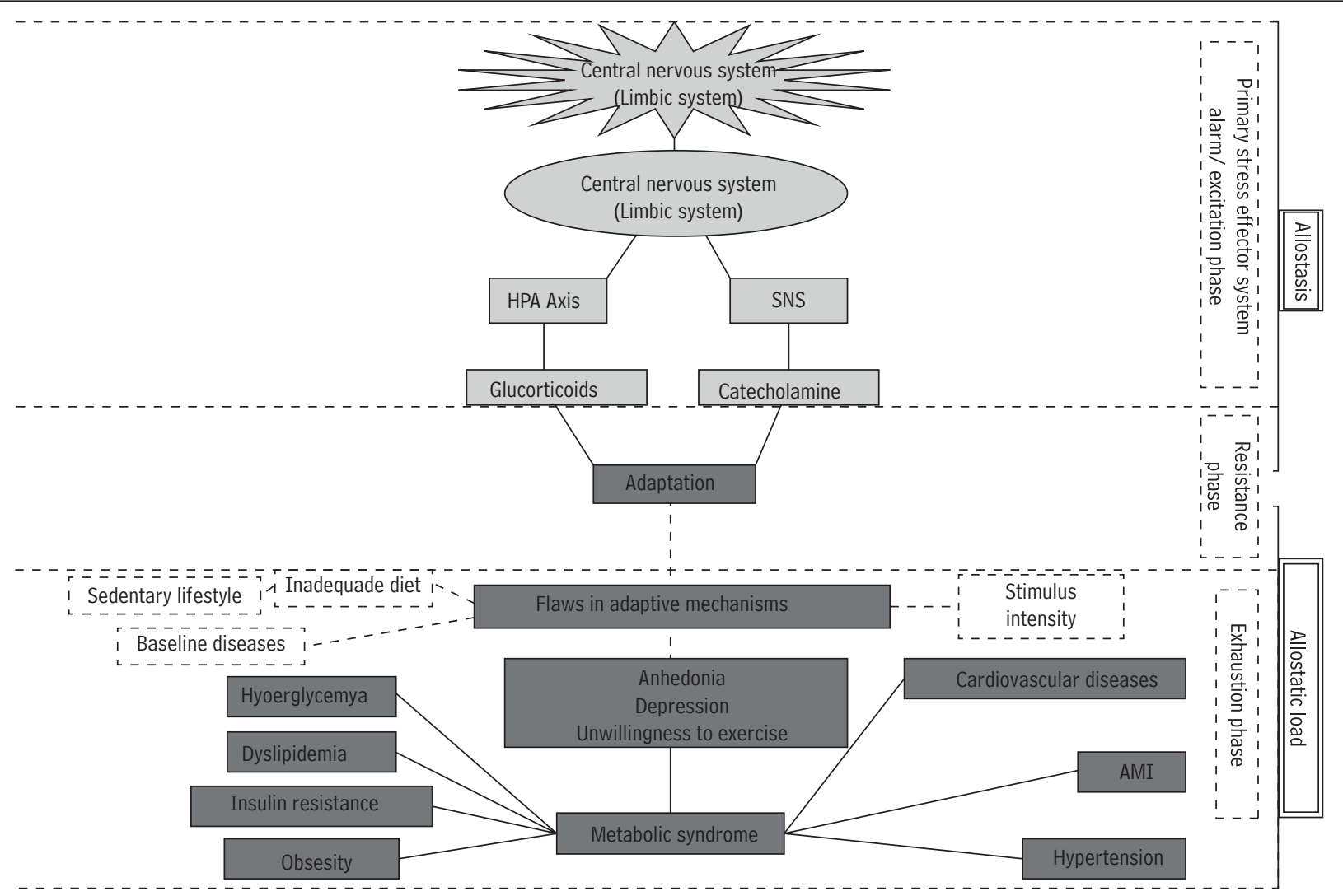

Figure 1 - Activation of the primary stress effector system, resistance and exhaustion phases: allostasis and allostatic load. HPA axis: Hypothalamus-pituitary-adrenal axis; SNS: Sympathetic Nervous System; AMI: Acute myocardial infarction.

Stress, depression and cardiovascular system

There is a vast literature describing the active participation of the cardiovascular system in the adaptive process in response to stress, either by increasing blood pressure or cardiac frequency, contractility or output (14). In a healthy body, short-term stressful activation is not only capable of triggering harmful responses, it also tends to promote essential protective effects that help in survival during imminent danger situations $(12,13)$. Thus, physiological blood pressure changes allow the body to adapt to physical and emotional changes by providing adequate blood flow to the tissues (12) and improving myocardial inotropic response to stimulation (15).

However, a deficiency of these adaptive mechanisms in conjunction with several factors such as the intensity of the stressor stimulus (13) and the individual characteristics of each body $(14,16)$, may trigger lethal deleterious effects. Acute and chronic stress participate actively in this process and are responsible for the hyperactivation of the sympathetic nervous system as well as the release of inflammatory mediators. These adaptations induce changes, such as hypertension, formation of atherosclerotic plaques (especially if associated with metabolic factors) (12), myocardial ischemia (17) and cardiomyopathy (18).

The high prevalence of cardiovascular disease due to the impact of stress in modern society is closely related to emotional disorders, such as depression. Approximately $60 \%$ of cases of depressive disorders are preceded by stress factors, especially of psychosocial origin (19). According to the Global Burden of Disease study (a collaboration between the Harvard Public Health School, the World Health Organization and the World Bank), it is estimated that depression will become the second most important cause of disease burden in the world by the year 2020 (20). Despite the lack of epidemiological studies in Brazil, data from the Ministry of Health show that about 10 million Brazilians suffer from depression (21). In Pelotas, Rio Grande do Sul, Brazil, approximately 
$29.4 \%$ of the population have depressive symptoms (22). Moreover, according to the 2008 National Survey by Household Sample (23), approximately $4.1 \%$ of the 59.5 million Brazilians diagnosed with a chronic disease also have depression. However, although depression represents a problem of great social impact, disease identification is still precarious, given that $50 \%$ to $60 \%$ of cases are not detected, do not receive specific information on the problem nor adequate treatment (24).

Depression is characterized by decreased sensitivity to reward (anhedonia), increased activity of the sympathetic nervous system and increased heart rate $(25,26)$. In addition, studies have already demonstrated a positive correlation among stress, cardiovascular changes and decreased heart rate variability (27), an important predictor of mortality (28).

Although the relationship between chronic stress and depression is not well established, it is known that depression can lead to a dysfunction of the HPA axis with continuous release of glucocorticoids (such as cortisol), impairment of negative feedback (essential for maintaining homeostasis), changes in the secretion of monoamines (such as serotonin and norepinephrine), and of immune system components through the release of pro-inflammatory cytokine.

There is a close relationship between stress and depression. Studies have demonstrated that changes in the functioning of the stress response system are related to the development of depression, since depressive patients have an increased concentration of circulating cortisol in the bloodstream and of cortisol in the urine (29), as well as increased corticotrophinreleasing factor (CRF) levels in the cerebrospinal fluid (30). Furthermore, an increased expression of messenger ribonucleic acid (mRNA) for CRF and concentration of this peptide as well as a downregulation of CRF receptors in the locus coeruleus, hypothalamus and raphe nucleus have been found in the postmortem brain tissue of depressed patients (31).

Thus, emotional disorders in response to chronic stress may be a risk factor for heart disease-related morbidity and mortality, which makes the response to emotional stress a possible marker for the processes involved in the development of cardiovascular disorders. Additionally, the presence of chronic exogenous stressors seems to interfere in the regulation of the emotional state and cardiovascular system, and trigger depressive states in experimental studies $(14,26)$. Of note, there is a bidirectional relationship between depression and cardiovascular disease, as 20 - 50\% of patients who died from myocardial infarction had previously suffered from depression (26). Conversely, the presence of cardiac diseases seems to increase the probability of occurrence of depressive states (25). Prevalence of depression may increase from 2 to $9 \%$ in the general population to $45 \%$ in patients who already had a heart attack (32).

This reality does not seem to be different for animals. Animal models have been very useful in the study of deleterious effects triggered by chronic stress, given the limitations inherent to research in which human participants are involved and in order to complement clinical and epidemiological studies. Although it is well established that rodents adapt to the repeated adminitration of stressors, this adaptation does not occur in the chronic unpredictable mild stress (CUMS) protocol $(33,34)$.

In the CUMS protocol, alternate exposure to different stressors induces a maintained elevation of corticosterone levels and an increase in anhedonia, evidenced by a decrease in the consumption of and preference for sweet solution. As these effects are reversed by tricyclic antidepressants and 5-HT1C receptor agonists, anhedonia induction by CUMS is a model of predictive validity for the study of mechanisms involved in human depression $(33,34)$.

Using the CUMS model proposed by Moreau et al. (33) and modified by Neves et al. (35), a study has found that rats submitted to CUMS showed higher corticosterone plasma concentrations, which indicates the non-adaptation of these animals to the stressors $(35,36)$. In addition, the authors found a decrease in the preference for and consumption of saccharose solution, which evidences that CUMS induced anhedonia in stressed animals (37). These adaptations were accompanied by cardiovascular changes - evidenced by supersensitivity to the vasoconstrictor effects of phenylephrine in aortic rings with intact endothelium, hypertrophy of the middle and inner aortic layer, increased triglyceride and total cholesterol levels as well as atherogenic index — that indicate that the administration of CUMS contributes to the development of atherosclerosis $(35,36)$.

Other studies on CUMS have shown that, in addition to anhedonia, this model also triggered an increase in plasma levels of tumor necrosis factor (TNF- $\alpha$ ), interleukin-1 (IL-1) beta, aldosterone (25), and heart rate at rest, as well as a decrease in heart rate variability and in the threshold of ventricular 
arrhythmias $(25,26)$, which demonstrates the deleterious effects of chronic stress on the cardiovascular system.

\section{Stress and metabolic changes}

During a stress reaction, catecholamines and glucocorticoids play a central role in the mobilization of energy substrates into the central nervous system, skeletal and cardiac muscle tissue. These hormones, in addition to stimulating glycogenolysis, lipolysis and proteolysis, inhibit glucose uptake in tissues whose function is not essential during exposure to the stressor (11). Thus, glucocorticoids are recognized to impair insulin-stimulated glucose uptake into the skeletal muscle, probably because they inhibit the translocation of GLUT4 glucose transporter from its inner membrane to the plasma membrane. Such inhibition may occur through the downregulation of various signaling proteins that are important in mediating tyrosine phosphorylation of the GLUT4 insulin receptor. Nevertheless, this mechanism of action is still controversial (38).

In stressful situations, there is a significant increase in insulin resistance and blood glucose (36, 39). In this case, cortisol stands out as the main glucocorticoid released in response to a stressing activity. It is able to significantly influence glucose metabolism, making glycemic control difficult (40) and promoting metabolic imbalance due to the constant stimulation of the sympathetic nervous system (41).

In fact, type 2 diabetic patients who are exposed to stressful situations tend to show increased cortisol secretion, which contributes to a worsening of glycemic control and insulin sensitivity, and leads to a higher prevalence of diabetes chronic complications (42). Wiesli et al (3) also demonstrated that, after being exposed to a psychosocial stress test, individuals with type 1 diabetes showed a significant decrease of glucose concentrations in the postprandial period. Further, it is important to note that stress can also stimulate the development of endocrine-metabolic disorders in non-diabetic patients who have a compromised health status and hence favor the onset of hyperglycemia (43). Greci et al. (44) have found that $60 \%$ of hyperglycemic patients treated in emergency rooms in the USA received a diagnosis of diabetes within one year (44). Close attention to these patients is therefore essential, because disease development can occur in a short period of time.

It is known that the effects of stress alter not only the glucose metabolism but also the metabolism of proteins and lipids. In a stress reaction, fatty acids can be derived from three sources: from the mobilization of adipose tissue; from increased synthesis of fatty acids triggerered by the combined effects of insulin and cortisol; and from an increased consumption of foods high in fats, which favors the production of remnant chylomicrons associated with hyperphagia (41). As a result, this increase in fatty acid levels is accompanied by a significant decrease in tissue insulin sensitivity and promotes the development of insulin resistance. The decrease in the action of insulin and the increased release of catecholamines and cortisol stimulate increased lipolysis and the mobilization of fatty acids and glycerol from adipose tissues, and, in this case, can also trigger muscle proteolysis. Amino acids, in conjunction with glycerol and lactate, provide the necessary precursors for gluconeogenesis, which, associated with the deficiency of insulin-regulatory mechanisms, facilitates the synthesis of hepatic triglycerides. Thus, the continuous high supply of fatty acids ultimately stimulates the secretion of VLDL (a very low-intensity lipoprotein) by the liver (41).

With regard to dietary habits, it is known that some people tend to lose while others tend to gain weight in response to stress. It is believed that this occurs due to an increased activation of $\beta$-adrenergic receptors, which can lead to weight loss due to its effect on the lipolysis mechanism, as mentioned above, or due to the increased consumption of convenience foods that are high in fats and sugars (45). GonzalezBono et al. (46) have also reported that both the fed and the fasting state can increase the activity of the HPA axis. This suggests the existance of different underlying mechanisms that participate in the interaction between the caloric flow and the levels of stress-related hormones such as cortisol.

Stress alone (depending on its type and intensity) or diet alone (depending on the kind of hypercaloric diet), however, may not be able to induce obesity, as stress has been found to often decrease adiposity in rats (45). Nevertheless, when combined, chronic stress and hyprcaloric diets may lead to abdominal obesity due to the direct release of a sympathetic neurotransmitter (neuropeptide $\mathrm{Y}$ ) in the adipose tissue (45). 
Studies have shown that obesity is a growing global health problem and affects over 400 million people worldwide. There are more than 45 comorbidities and atherogenic disorders associated with obesity. Furthermore, it is recognized in the International Diabetes Federation guidelines as a progressive condition that contributes to the development of diabetes and cardiovascular disorders, and to mortality due to such causes (47).

Hotamisligil et al. (48) had already shown that obesity could be characterized as a "low-grade systemic inflammation" induced by different inflammatory mediators such as mononuclear cells, lymphocytes, C-reactive protein, TNF- $\alpha$, IL- 1 and interleukin-6 (IL - 6) (49). In the same way as obesity favors the release of inflammatory mediators, chronic stress seems to interfere with the immune response, causing a marked decrease in the proliferation of $B$ and $\mathrm{T}$ cells in diabetic mice, when compared to the control group (39) as well as immunosuppression, release of pro-inflammatory cytokines and excess cortisol, which are also present in patients diagnosed with depression $(25,26)$.

Chronic stress, when associated with diets high in sugars and fats, first induces increases in glucocorticoid levels in visceral fat, and then, through angiogenesis and adipogenesis, tends to induce a growth of the abdominal area, which over time leads to tissue inflammation, hypervascularization and hormonal changes such as hyperinsulinemia and hyperlipidemia (45). This demonstrates that a cross-talk between metabolic and inflammatory signaling pathways worsens the effect of insulin on the peripheral tissue (49) and is related to the pro-inflammatory state that results from obesity and stress, insulin resistance and diabetes $(45,47)$.

It is known that, when associated with hypertension, glucose and lipid metabolic dysfunctions, like several atherogenic disorders triggered by obesity (47) lead to the onset of a multifactorial disease called metabolic syndrome (MS) (50). The incidence of MS has been increasing worldwide and is a result of the so-called modern Western lifestyle. The main negative aspects of this lifestyle include a positive energy balance, poor diet and sleep quality, and stress (50, 51). The latter can favor the development of MS (50), a risk factor for type 2 Diabetes Mellitus and cardiovascular diseases (52). Li et al. (52) have found an inversely proportional relationship between the ocurrence of hypertension, diabetes, abdominal obesity, and high blood glucose concetrations in 1206 volunteers, when compared to stress and anxiety levels, which decreased as metabolic changes increased.

Seematter et al. (53) have found that lean individuals subjected to mental stress became predisposed to increased glucose uptake and energy expenditure, and produced vasodilation and activation of $\beta$-adrenoceptors involved in these responses, whereas in obese individuals mental stress interfered with glucose absorption and systemic vascular resistance, and energy expenditure diminished. In addition, occupational stress also changed the metabolic parameters related to glucose and lipid metabolism in individuals who experienced greater psyhological demands, making them susceptible to the development of MS (54). The greater the perception of stress intensity at work, the greater the risk of being affected by such changes (55).

Stress, cardiovascular and metabolic disorders, exercise and physical activity

Improved quality of life has been the main driving force in the quest for longevity. According to the Medical Expenditure Panel Survey (MEPS) (56), the total expenditure on health care and the costs of work loss due to chronic diseases such as hypertension, heart disease, diabetes and mood-related disorders in the USA was approximately 306 billion US dollars between the years 1996 and 1998. The costs for treating hypertension and its complications were estimated at 15 to 60 billion US dollars in the period mentined above and at approximately 177.5 billion US dollars in 1997 (57). In addition, it is estimated that these costs may triple between 2010 and 2030 (from 273 to 818 billion US dollars). The costs resulting from lost productivity are also expected to grow from 172 to 276 billion US dollars (5).

Although alarming, complications arising from poor lifestyle choices may be minimized and/or controlled by means of curative or prophylactic measures (either pharmacological or not) (6). Physical exercise has a prominent position in this context, being recognized as a key factor for the maintenance of health (7). Fitness benefits may be gained from aerobic exercise (8), resistance training or a combination of both (9). It is known that physical exercise is a subcategory of physical activity (defined as any body movement purposive to generate muscle contractions and caloric 
expenditure) that is planned structured and repetitive $(58,59)$. Thus, both physical activity and physical exercise can provide good results $(58,59,60,61,62)$.

Thus, physical activity can reduce the perception of stress, as lower levels of stress are generally associated with better physical health (58). Of note, the benefits of exercise for health are more pronounced in individuals with higher stress levels when compared to individuals with lower stress levels (59). In addition, studies have shown decreased reactivity of the HPA axis in response to psychological stress in older persons and physically trained individuals, when compared to untrained subjects. This indicates that physical activity may attenuate cortisol release in response to stress (60).

Although much is discussed about the benefits of physical exercise (which sometimes can be influenced by microRNAs) (61), exercise can also be recognized as a stress paradigm depending on the way it is used (1), because its effects on the immune system are mediated by hormones like cortisol and catecholamines. Nevertheless, in stress situations, both exercise and physical activity are able to trigger a feeling of satisfaction and well-being (62). This favors the health of older individuals with high levels of stress, as measured with the Perceive Stress Scale in a longitudinal study (63). Thus, physical activity may promote physical and psychological benefits that are involved in both the indirect action of exercise in reducing stress, and a direct effect on various metabolic functions of the body (4). Physical activity exerts quick tranquilizing effects (also due to the increase in body temperature), while regular exercise reduces the concentration of circulating insulin, stimulates the activity of the adrenal gland and the secretion of norepinephrine, serotonin, $\beta$-endorphin and dopamine (improving mood). In addition, exercise stimulates the release of thyroid hormones, estrogen, progesterone, testosterone and leptin (62) and reduces the activity of the HPA axis in response to repeated stress (64) (Figure 2). Indeed, Sanches et al. (65) have found that moderate-intensity aerobic exercise practiced in a playful way by type 2 diabetes patients $(3$ times/week for three consecutive months) reduced systolic and diastolic blood pressure, body mass index, blood glucose and LDL-cholesterol (low-intensity lipoprotein) as wel as salivary cortisol concentration and anxiety and depression levels as assessed by the HADS (Hospital Anxiety and Depression Scale). However, it is important to note that, depending on the intensity of exercise, there may be the stimulation of lymphocytes and white blood cells, and the release of pro- and anti-inflammatory cytokines (TNF- $\alpha$, IL-1 and IL- 6), which could lead to harmful adaptations (66). On the other hand, independent of exercise intensity, the interruption of exercise performance tends to affect good mood, probably due mechanisms related to decreases in IL - 6 (67), an important cytokine that mobilizes extracellular substrates during exercise (68).

Because it promotes a wellness feeling and improves mental health, exercise is also recommended as a complementary therapy in the treatment of individuals who suffer from depression. After evaluating some epidemiological studies, Hamer et al. (69) have shown that the risk of developing depressive symptoms was reduced by $22 \%$ in physically active individuals. In this case, it is believed that the mechanisms responsible for this change are related to both psychological aspects (such as distraction, improved mood, self-esteem and social interaction) and the increased release of monoamines and endorphins, and stimulation of synaptic transmission, which have inhibitory effects on the central nervous system (70). Additionally, it is important to note that physically inactive patients who have depressive symptoms also have increased risk of cardiovascular mortality (71), while exercise can inhibit the occurrence of depression and depressive symptoms, improve mental health and increase survival in patients who have suffered acute myocardial infarction (72). Regarding the hippocampus, a clinical study has found that depressed patients who practiced physical activity had increased hippocampal volume compared with sedentary, depressed patients (73).

Voluntary aerobic exercise (wheel running) was found to reduce anhedonia in rats. This suggests that exercise training can induce biological changes that are similar to those induced by antidepressant drugs (74). In the central nervous system, exercise can increase the release of brain-derived neurotrophic factor (BDNF), which is known to improve the health and survival of nerve cells. This suggests that exercise may influence brain health (75). Exercise can also alter monoamine levels in the brain during stress (76). He et al. have shown that exercise by swimming prevented and reversed the decrease in hippocampal serotonin and noradrenaline induced by chronic stress and promoted an increase in dopamine levels in the hippocampus when performed before the beginning of the stress period (76). Furthermore, exercise may play an important role in protecting the hippocampus against damages caused by exposure to glucocorticoids that 
are secreted during stress (77) as studies have shown that physical activity is capable of stimulating the proliferation of hippocampal cells (78), changing synaptic plasticity, and stimulating neurogenesis and synaptogenesis (79). Other findings suggest that the benefits of physical activity for depressive states may be closely related not only to the neurogenesis in the hippocampus but also with the angiogenesis in the brain. In this context, Kiuchi et al. (80) have demonstrated that physical training (treadmill running) in mice was associated with improved depressive behavior and decreased density of blood vessels and neurogenesis in the hippocampus. In addition, when the authors associated these responses with an inhibitor of vascular endothelial growth factor receptor - an important factor that stimulates the development of blood vessels and has antidepressive action - the antidepressive effect of exercise was cancelled (80).

\section{Final Considerations}

Considering the dysfunctions triggered in response to chronic mental stress and the positive results gained from exercise, the data of this review suggest that, although sedentary lifestyle, chronic stress, depression, genetic predisposition and poor diet are primary risk factors for the development of cardiovascular and metabolic complications, regular exercise/physical activity may minimize these effects by preventing or mitigating the development of various diseases and thus contribute to an increase in life expectancy and an improvement in quality of life (62). In conclusion, regular physical exercise is useful and inexpensive way of maintaining health, especially with respect to improving mood and mental stress.

\section{Acknowledgements:}

We are grateful for the financial support granted by the São Paulo Research Foundation (FAPESP 2010/51904-9), the Brazilian National Council for Scientific and Technological Development (CNPq 459056/2014-0 and 140926/2012-7) and the Brazilian Higher Education Coordination Agency (CAPES).

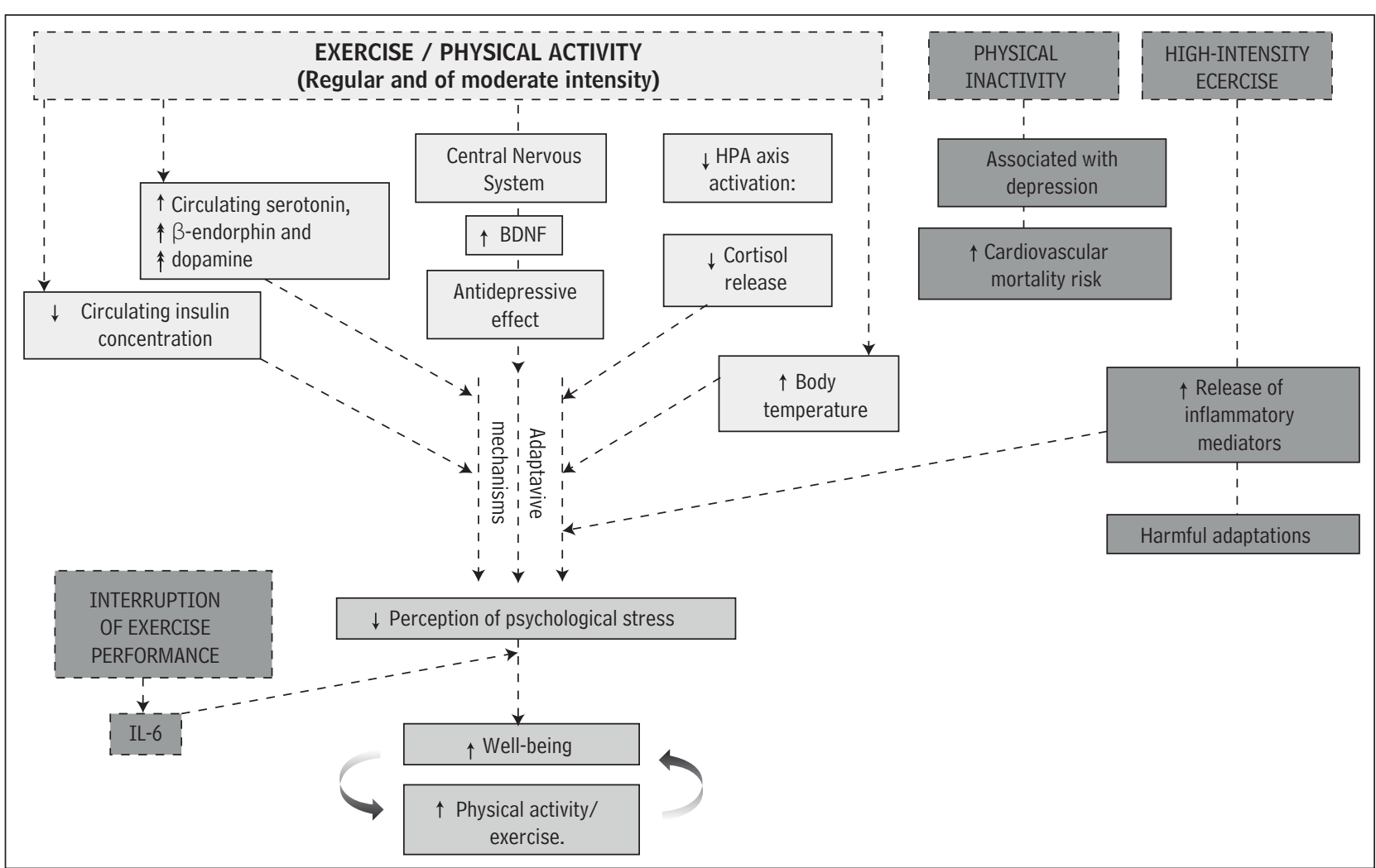

Figure 2 - Physiological effects of exercise and physical activity: Adaptive mechanisms that contribute to a decreased perception of chronic stress. BDNF: Brain-derived neurotrophic factor; HPA axis: hypothalamic-pituitary-adrenal axis; IL-6: Interleukin-6. 


\section{References}

1. Goldstein DS, Kopin IJ. Evolution of concepts of stress. Stress. 2007;10(2):109-20.

2. Chrousos GP, Gold PW. The concepts of stress and stress system disorders. Overview of physical and behavioral homeostasis. JAMA. 1992;267(9):1244-52.

3. Wiesli P, Schmid C, Kerwer O, Nigg-Koch C, Klaghofer R, Seifert B, et al. Acute psychological stress affects glucose concentrations in patients with type 1 diabetes following food intake but not in the fasting state. Diabetes Care. 2005;28(8):1910-5.

4. Marcondes FK, Neves VJ, Costa R, Sanches A, Cunha TS, Moura MJ, et al. Dyslipidemia induced by stress. In: Prof. Roya Kelishadi (Eds). Dyslipidemia - From prevention to treatment. Rijeka: Intech; 2012. 367-90.

5. Heidenreich PA, Trogdon JG, Khavjou OA, Butler J, Dracup K, Ezekowitz MD et al. Forecasting the future of cardiovascular disease in the United States: a policy statement from the American Heart Association. Circulation. 2011;123(8):933-44.

6. Pugliese R, Zanella MT, Blay SL, Plavinik F, Andrade MA, Galvão R. Efficacy of lifestyle change psychological intervention in coronary risk reduction. Arq Bras Cardiol. 2007;89(4):225-30.

7. Martínez de Morentin PB, López M. "Mens sana in corpore sano": exercise and hypothalamic ER stress. PLoS Biol. 2010;8(8):pii:e1000464.

8. Monteiro LZ, Fiani CR, Freitas MC, Zanetti ML, Foss MC. Decrease in blood pressure, body mass index and glycemia after aerobic training in elderly women with type 2 diabetes. Arq Bras Cardiol. 2010;95(5):563-70.

9. Fett CA, Fett WC, Marchini JS. Circuit weight training vs jogging in metabolic risk factors of overweight/ obese women. Arq Bras Cardiol. 2009;93(5):519-25.

10. Selye H. A syndrome produced by diverse nocuous agents. Nature. 1936;138(1):32.

11. Tanno AP, Marcondes FK. Estresse, ciclo reprodutivo e sensibilidade cardíaca às catecolaminas. Rev. Bras. Cienc. Farm. 2002;38(3):273-289.

12. McEwen BS. Stressed or stressed out: what is the difference? J Psychiatry Neurosci. 2005;30(5):315-8.
13. Loures DL, Sant Anna I, Baldotto CS, Sousa EB, Nóbrega AC. Mental stress and cardiovascular system. Arq Bras Cardiol. 2002;78(5):525-30.

14. Krantz DS, Manuck SB. Acute psychophysiologic reactivity and risk of cardiovascular disease: a review and methodologic critique. Psychol Bull. 1984;96(3):435-64.

15. Bruder-Nascimento T, Campos DH, Leopoldo AS, Lima-Leopoldo AP, Okoshi K, Cordellini S, et al. Chronic stress improves the myocardial function without altering L-type $\mathrm{Ca}+2$ channel activity in rats. Arq Bras Cardiol. 2012. [Epub ahead of print]

16. De Mattos CE, de Mattos MA, Toledo DG, de Siqueira Filho AG. Using ambulatory blood pressure monitoring to assess blood pressure of firefighters with parental history of hypertension. Arq Bras Cardiol. 2006;87(6):741-6.

17. Barbirato GB, Félix R, de Azevedo JC, Corrêa PL, de Nóbrega AC, Coimbra A, et al. Prevalence of induced ischemia by mental distress. Arq Bras Cardiol. 2010;94(3):321-7.

18. Lemos AE, Junior Araújo AL, Lemos MT, Belém Lde S, Vasconcelos Filho FJ, Barros RB. Broken-heart syndrome (Takotsubo syndrome). Arq Bras Cardiol. 2008;90(1):e1-3.

19. Post RM. Transduction of psychosocial stress into the neurobiology of recurrent affective disorder. Am J Psychiatry. 1992;149(8):999-1010.

20. Lopez AD, Murray CC. The global burden of disease, 1990-2020. Nat Med. 1998;4(11):1241-3.

21. Ministério da Saúde. Depressão é parceira indesejável de 10\% dos idosos. [cited in jun 2011]. Available from: http://portal.saude.gov.br/saude/visualizar_texto. cfm?idtxt=19108

22. Rombaldi AJ, da Silva MC, Gazalle FK, Azevedo MR, Hallal PC. Prevalence of depressive symptoms and associated factors among southern Brazilian adults: cross-sectional population-based study. Rev Bras Epidemiol. 2010;13(4):620-9.

23. Pesquisa Nacional por Amostra de Domicílios. PNAD 2008 - Um Panorama da Saúde no Brasil. [Cited in dez 2011]. Available from : http://www.ibge.gov. br/home/presidencia/noticias/noticia_visualiza. php?id_noticia $=1580 \&$ 
24. Lima AF, Fleck MP. Quality of life, diagnosis, and treatment of patients with major depression: a prospective cohort study in primary care. Rev Bras Psiquiatr. 2011;33(3):245-51.

25. Grippo A, Francis J, Beltz TG, Felder RB, Johnson AK. Neuroendocrine and cytokine profile of chronic mild stress-induced anhedonia. Physiology \& Behavior. 2005;84:697-706.

26. Grippo AJ, Johnson AK. Stress, depression and cardiovascular dysregulation: a review of neurobiological mechanisms and the integration of research from preclinical disease models. Stress. 2009;12(1):1-21.

27. Mezzacappa ES, Kelsey RM, Katkin ES, Sloan RP. Vagal rebound and recovery from psychological stress. Psychosom Med. 2001;63(4):650-7.

28. La Rovere MT, Bigger JT Jr, Marcus FI, Mortara A, Schwartz PJ. Baroreflex sensitivity and heart-rate variability in prediction of total cardiac mortality after myocardial infarction. ATRAMI (Autonomic Tone and Reflexes After Myocardial Infarction) Investigators. Lancet. 1998;351(9101):478-84.

29. Gold PW, Drevets WC, Charney DS. New insights into the role of cortisol and the glucocorticoid receptor in severe depression. Biol Psychiatry. 2002;52(5):381-5.

30. Nemeroff CB, Owens MJ, Bissette G, Andorn AC, Stanley M. Reduced corticotropin releasing factor binding sites in the frontal cortex of suicide victims. Arch Gen Psychiatry. 1988;45(6):577-9.

31. Raadsheer FC, Hoogendijk WJ, Stam FC, Tilders FJ, Swaab DF. Increased numbers of corticotropin-releasing hormone expressing neurons in the hypothalamic paraventricular nucleus of depressed patients. Neuroendocrinology. 1994;60(4):436-44.

32. American Psychiatric Association. Mood Disorders. In: Allen Frances (Eds). Diagnostic and statistical manual of mental disorders, $4^{\text {th }}$ ed. Washington, DC: American Psychiatric Publishing; 2000:345-428.

33. Moreau JL, Jenck F, Martin JR, Perrin S, Haefely WE. Effects of repeated mild stress and two antidepressant treatments on the behavioral response to $5 \mathrm{HT} 1 \mathrm{C}$ receptor activation in rats. Psychopharmacology (Berl). 1993;110(1-2):140-4.
34. Willner P. Chronic mild stress (CMS) revisited: consistency and behavioural-neurobiological concordance in the effects of CMS. Neuropsychobiology. 2005;52(2):90-110.

35. Neves VJ, Moura MJCS, Tamascia ML, Ferreira R, Silva NS, Costa R et al. Proatherosclerotic effects of chronic stress in male rats: Altered phenylephrine sensitivity and nitric oxide synthase activity of aorta and circulating lipids. Stress. 2009;12(4):320-327.

36. Neves VJ, Moura MJ, Almeida BS, Costa R, Sanches A, Ferreira R, et al. Chronic stress, but not hypercaloric diet, impairs vascular function in rats. Stress. 2012;15(2):138-48.

37. Costa R, Briet LS, Tamascia ML, Almeida BS, Sanches A, Marcondes FK. Chronic mild and unpredictable stress affects depression behavior, but not anxiety-like behavior In: XXVI Reunião Anual da FeSBE; 2011 Aug 24-27. Proceedings. Rio de Janeiro, 2011[CD-ROM]. AbstractID: 96-1.

38. Van Cromphaut SJ. Hyperglycaemia as part of the stress response: the underlying mechanisms. Best Pract Res Clin Anaesthesiol. 2009;23(4):375-86.

39. Rubinstein MR, Cremaschi GA, Oliveri LM, Gerez EN, Wald MR, Genaro AM. Possible involvement of stress hormones and hyperglycaemia in chronic mild stressinduced impairment of immune functions in diabetic mice. Stress. 2010;13(5):384-91.

40. Nowotny B, Cavka M, Herder C, Löffler H, Poschen U, Joksimovic L, et al. Effects of acute psychological stress on glucose metabolism and subclinical inflammation in patients with post-traumatic stress disorder. Horm Metab Res. 2010;42(10):746-53.

41. Brindley DN, McCann BS, Niaura R, Stoney CM, Suarez EC. Stress and lipoprotein metabolism: modulators and mechanisms. Metabolism. 1993;42(9):3-15.

42. Chiodini I, Adda G, Scillitani A, Coletti F, Morelli V, Di Lembo $S$, et al. Cortisol secretion in patients with type 2 diabetes: relationship with chronic complications. Diabetes Care. 2007;30(1):83-8.

43. Müller B. Endocrine aspects of critical illness. Ann Endocrinol (Paris). 2007, 68(4):290-8. 
44. Greci LS, Kailasam M, Malkani S, Katz DL, Hulinsky I, Ahmadi R, Nawaz H. Utility of HbA (1c) levels for diabetes case finding in hospitalized patients with hyperglycemia. Diabetes Care. 2003;26(4):1064-8.

45. Kuo LE, Czarnecka M, Kitlinska JB, Tilan JU, Kvetnanský R, Zukowska Z. Chronic stress, combined with a high-fat/high-sugar diet, shifts sympathetic signaling toward neuropeptide $\mathrm{Y}$ and leads to obesity and the metabolic syndrome. Ann N Y Acad Sci. 2008;1148:232-7.

46. Gonzalez-Bono E, Rohleder N, Hellhammer DH, Salvador A, Kirschbaum C. Glucose but not protein or fat load amplifies the cortisol response to psychosocial stress. Horm Behav. 2002;41(3):328-33.

47. Lois K, Kumar S. Obesity and diabetes. Endocrinol Nutr. 2009;56S4: 38-42.

48. Hotamisligil GS, Shargill NS, Spiegelman BM. Adipose expression of tumor necrosis factor-alpha: direct role in obesity-linked insulin resistance. Science. 1993;259(5091):87-91.

49. Senn JJ, Klover PJ, Nowak IA, Mooney RA. Interleukin-6 induces cellular insulin resistance in hepatocytes. Diabetes. 2002;51(12):3391-9.

50. Ludwig MWB, Bortolon C, Feoli AM, Macagnan, FE, Oliveira MS. Ansiedade, depressão e estresse em pacientes com síndrome metabólica. Arquivos Brasileiros de Psicologia. 2012;64(1):31-46.

51. Lo CM, Lee PH. Prevalence and impacts of poor sleep on quality of life and associated factors of good sleepers in a sample of older Chinese adults. Health Qual Life Outcomes. 2012;10:72.

52. Li JB, Wang X, Zhang JX, Gu P, Zhang X, Chen CX, et al. Metabolic syndrome: prevalence and risk factors in southern China. J Int Med Res. 2010;38(3):1142-8.

53. Seematter G, Guenat E, Schneiter P, Cayeux C, Jéquier E, Tappy L. Effects of mental stress on insulin-mediated glucose metabolism and energy expenditure in lean and obese women. Am J Physiol Endocrinol Metab. 2000;279(4):799-805.

54. Costa MB, Guércio NMS, Costa HFC, de Oliveira MME, Alves MJM. Possível relação entre estresse ocupacional e síndrome metabólica. HU Revista. 2011;37(1):87-93.
55. Martinez MC, Latorre Mdo R. Risk factors for hypertension and diabetes mellitus in metallurgic and siderurgic company's workers. Arq Bras Cardiol. 2006;87(4):471-9.

56. Basu R, Krueger PM, Lairson DR, Franzini L. Lifetime medical expenditures among hypertensive men and women in the United States.Womens Health Issues. 2011;21(3):246-53.

57. Balu S. Estimated annual direct expenditures in the United States as a result of inappropriate hypertension treatment according to national treatment guidelines. Clin Ther. 2009;31(7):1581-94.

58. Salmon P. Effects of physical exercise on anxiety, depression, and sensitivity to stress: a unifying theory. Clin Psychol Rev. 2001;21(1):33-61.

59. Carmack CL, Boudreaux E, Amaral-Melendez M, Brantley PJ, de Moor C. Aerobic fitness and leisure physical activity as moderators of the stress-illness relation. Ann Behav Med. 1999;21(3):251-7.

60. Traustadóttir T, Bosch PR, Matt KS. The HPA axis response to stress in women: effects of aging and fitness. Psychoneuroendocrinology. 2005;30(4):392-402.

61. Fernandes-Silva MM, Carvalho VO, Guimarães GV, Bacal F, Bocchi EA. Physical exercise and microRNAs: new frontiers in heart failure. Arq Bras Cardiol. 2012;98(5):459- 66.

62. Schnohr P, Kristensen TS, Prescott E, Scharling H. Stress and life dissatisfaction are inversely associated with jogging and other types of physical activity in leisure time--The Copenhagen City Heart Study. Scand J Med Sci Sports. 2005;15(2):107-12.

63. Rueggeberg R, Wrosch C, Miller GE. The different roles of perceived stress in the association between older adults' physical activity and physical health. Health Psychol. 2012;31(2):164-71.

64. Nyhuis TJ, Masini CV, Sasse SK, Day HE, Campeau S. Physical activity, but not environmental complexity, facilitates HPA axis response habituation to repeated audiogenic stress despite neurotrophin mRNA regulation in both conditions. Brain Res. 2010;1362:68-77.

65. Sanches A, Peressim LB, Rocha SS. Efeito do exercício físico nas alterações cardiovasculares e metabólicas no diabetes mellitus tipo 2. [Monograph]. Americana: Faculdade de Americana; 2008. 
66. Suchánek O, Podrazil M, Fischerová B, Bočínská H, Budínský V, Stejskal D, Spíšek R, Bartůňková J, Kolář P Intensive physical activity increases peripheral blood dendritic cells. Cell Immunol. 2010;266(1):40-5.

67. Poole L, Hamer M, Wawrzyniak AJ, Steptoe A. The effects of exercise withdrawal on mood and inflammatory cytokine responses in humans. Stress. 2011;14(4):439-47.

68. Petersen AM, Pedersen BK. The anti-inflammatory effect of exercise. J Appl Physiol. 2005;98(4):1154-62.

69. Hamer M, Endrighi R, Poole L. Physical activity, stress reduction, and mood: insight into immunological mechanisms. Methods Mol Biol. 2012;934:89-102.

70. Peluso MA, Guerra de Andrade LH. Physical activity and mental health: the association between exercise and mood. Clinics (Sao Paulo). 2005;60(1):61-70.

71. Kamphuis MH, Geerlings MI, Tijhuis MA, Giampaoli S, Nissinen A, Grobbee DE, et al. Physical inactivity, depression, and risk of cardiovascular mortality. Med Sci Sports Exerc. 2007;39(10):1693-9.

72. Blumenthal JA, Babyak MA, Carney RM, Huber M, Saab PG, Burg MM, et al. Exercise, depression, and mortality after myocardial infarction in the ENRICHD trial. Med Sci Sports Exerc. 2004;36(5):746-55.

73. Head D, Singh T, Bugg JM. The moderating role of exercise on stress-related effects on the hippocampus and memory in later adulthood. Neuropsychology. 2012;26(2):133-43.
74. Greenwood BN, Foley TE, Day HE, Campisi J, Hammack, SH, Campeau S, et al. Freewheel running prevents learned helplessness/behavioral depression: role of dorsal raphe serotonergic neurons. J Neurosci. 2003;23(7):2889-98.

75. Yarrow JF, White LJ, McCoy SC, Borst SE. Training augments resistance exercise induced elevation of circulating brain derived neurotrophic factor (BDNF). Neurosci Lett. 2010;479(2):161-5.

76. He SB, Tang WG, Tang WJ, Kao XL, Zhang CG, Wong XT. Exercise intervention may prevent depression. Int J Sports Med. 2012;33(7):525-30.

77. Sigwalt AR, Budde H, Helmich I, Glaser V, Ghisoni K, Lanza S, et al. Molecular aspects involved in swimming exercise training reducing anhedonia in a rat model of depression. Neuroscience. 2011;192:661-74.

78. Ehninger D, Kempermann G. Regional effects of wheel running and environmental enrichment on cell genesis and microglia proliferation in the adult murine neocortex. Cereb Cortex. 2003;13(8):845-51.

79. Castrén E. Is mood chemistry? Nature reviews Nat Rev Neurosci. 2005;6(3):241-6.

80. Kiuchi T, Lee H, Mikami T. Regular exercise cures depression-like behavior via VEGF-Flk-1 signaling in chronically stressed mice. Neuroscience. 2012;207:208-17.

Recebido: 02/08/2013

Received: 08/02/2013

Aprovado: 19/06/2015

Approved: 06/19/2015 
